\title{
A LATE EFFECT ON THE CERVICAL SPINE IN ANKYLOSING SPONDYLITIS
}

BY

\author{
WILLIAM MARTEL, JOHN F. HOLT, AND WILLIAM D. ROBINSON \\ From the Departments of Radiology and Internal Medicine (Rackham Arthritis Research Unit), \\ University of Michigan, Ann Arbor, Mich.
}

Adults with advanced ankylosing spondylitis will occasionally exhibit a dramatic resorption of bone from the anterior surface of the cervical spine. This may be confused with the vertebral growth disturbances of juvenile rheumatoid arthritis and an erroneous inference may be drawn that in these cases ankylosing spondylitis must necessarily have begun in childhood (Wilkinson and Bywaters, 1958). It seems pertinent to call attention to this finding to emphasize that it may be acquired in adulthood and is not a "growth disturbance".

\section{Case Reports}

Case 1, a 43-year-old male, first noted stiffness and pain in the back with radiation down both thighs in 1939 . These symptoms gradually progressed and he developed arthritis of both hips for which he was admitted to the University Hospital in 1944. Physical examination showed moderate rigidity and kyphosis of the dorsolumbar spine and limitation of motion in both hips. Chest expansion was reduced. Neck motion was normal. There were no rheumatoid nodules. Radiological examination disclosed ankylosis of both sacroiliac joints and dorsolumbar spondylitis with "squaring" of the vertebral bodies, paraspinal ossifications, and fusion of the apophyseal joints. The hips were involved, but the cervical spine was normal (Fig. 1a). A diagnosis of ankylosing spondylitis was made and radiation therapy gave some relief of symptoms.

He was seen again in 1949 for recurrent episodes of faintness which were not relieved by food and were unrelated to posture. Physical examination now showed extreme kyphosis and spinal rigidity. Neck motion was partially limited. Neurological examination was negative. Cervical spine films (Fig. 1b) showed a dramatic resorption of bone from the anterior surfaces of $\mathrm{C} 4$, 5 , and 6 , so that the antero-posterior diameters of these vertebral bodies were reduced. The anterior margin of the cervical spine was continuous and smooth, as though it had been "planed down". The apophyseal joints seen in the lateral projection were fused, the intervertebral disks were reduced in height, and many were partially calcified, and the bones were demineralized. The cause of these symptoms was uncertain. The results of an oral

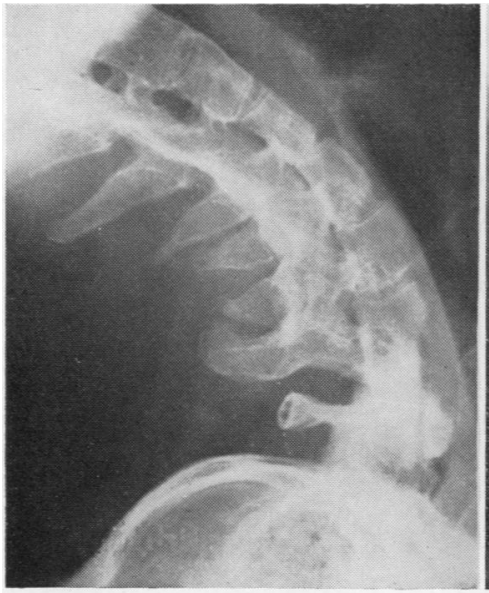

(a)

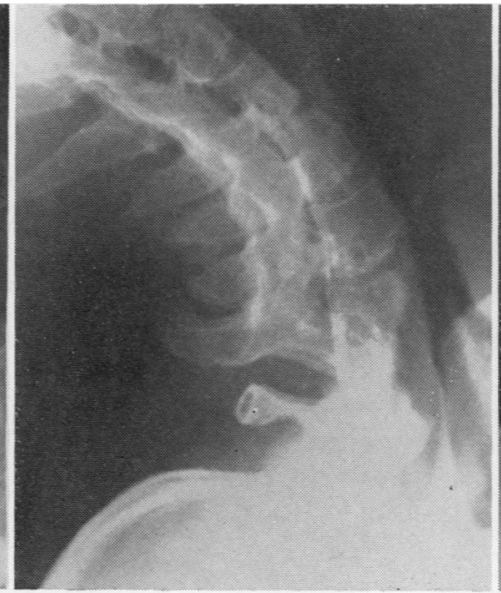

(b)

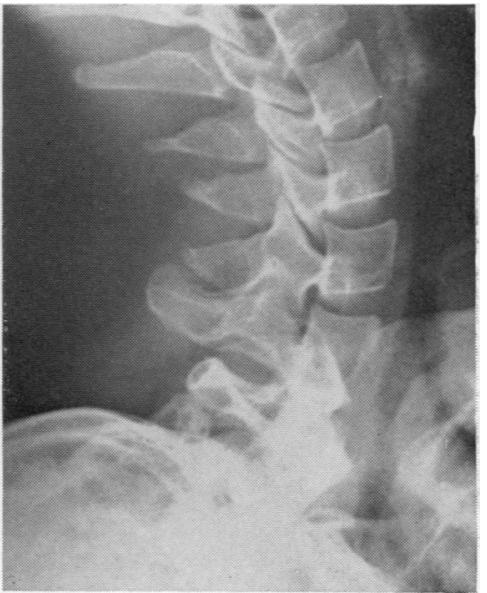

(c)

Fig. 1.-Case 1. (a) 1944 at age 27. Normal cervical spine. (b) 1949. (c) 1954 . Extensive, progressive resorption of bone from the anterior surface of $\mathrm{C4}, 5$, and 6 . The vertical dimensions of these vertebral bodies are preserved. Note apophyseal ankylosis and atrophy of intervertebral disks. 
glucose tolerance test suggested functional hypoglycaemia, but the symptoms continued despite a high carbohydrate diet. He was again seen in 1954 because of an exacerbation of the arthritis. Cervical spine films (Fig. 1c) at this time showed further resorption of bone from the anterior aspect of the cervical spine. Films were again obtained in 1960 and these showed no significant change, though flexion and extension views demonstrated fair motion in the atlanto-occipital and atlantoaxial joints.

Case 2, a 44-year-old male, first developed progressive pain and stiffness of the lumbar spine at the age of 20 years. Arthritis of the hips and shoulders began 5 years later. When the patient was first seen at the University Hospital in 1944, he had marked limitation of motion of the entire spine, including the cervical region. There was marked kyphosis of the dorsolumbar spine, and chest expansion was diminished. There was arthritis of the hips, shoulders, knees, and several joints of the right hand and left foot. Neurological examination was negative. Radiological examination showed typical, far-advanced changes of ankylosing spondylitis with extensive paraspinal ossifications, "squaring", and ankylosis of the sacro-iliac, apophyseal, and costovertebral joints. Cervical spine films were not obtained.

In $1954 x$-ray films showed progression of these changes and severe kyphosis of the dorsolumbar spine. The cervical apophyseal joints were completely ankylosed and there was resorption of bone from the anterior surface of $\mathrm{C} 6$ and $\mathrm{C7}$ and T1 (Fig. 2). Extensive ligamentous ossification was present. The intervertebral disks were atrophic and partially calcified and the vertebrae were demineralized.

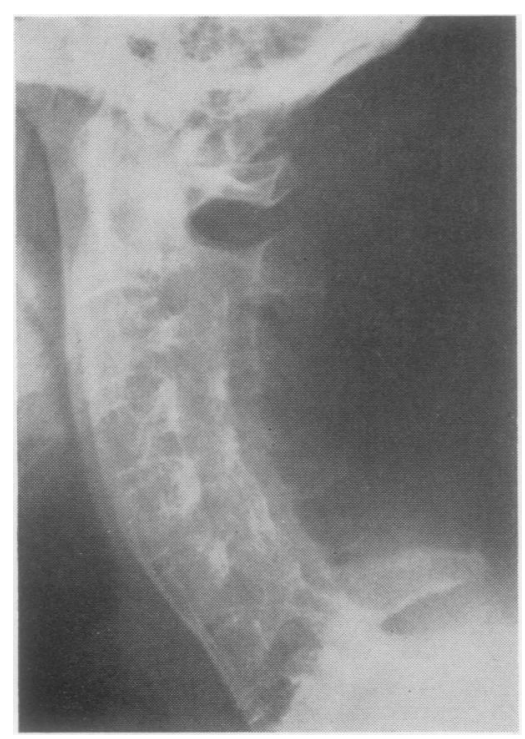

Fig. 2.-Case 2. 1954 at age 38. Resorption of bone similar to that shown in Fig. 1 has taken place at $\mathrm{C6}$ and 7 and T1. Advanced ankylosing spondylitis of the entire spine was present.

\section{Comment}

Superficial erosions of the anterior surfaces of the vertebrae, so-called "anterior spondylitis", are well known in ankylosing spondylitis and account for the characteristic "squaring" of the vertebral bodies (Romanus and Ydén, 1955). These erosions arê frequent in the dorsolumbar region, but may als $\mathbb{Q}$ be observed in the cervical spine. The vertebras changes which are illustrated are remarkable in that the loss of bone substance was so extreme and occurred predominantly in the cervical region. WE have noted this now in several patients with advanceg ankylosing spondylitis. It seems to be a late man: festation associated with complete ankylosis and extreme kyphosis of the dorsolumbar spine, such that the cervicodorsal segments tend to be horizontat with the patient in the upright position. Continuab hyperextension of the neck becomes necessary to permit the patient to look forward rather than down. One may postulate that, as a result of this continuat stress, a physiological resorption of bone occurs at the anterior, convex surface of the cervical arch by Wolff's law of transformation (Weinmann and Sicher, 1955). It is likely that this effect is superimposed on superficial erosions in this region, and thereby accounts for this degree of bone loss. The particular segments which undergo this transforma tion vary and this probably depends on the preceding pattern of ankylosis.

Apophyseal ankylosis is a common sequel to th $\overrightarrow{\vec{E}}$ spondylitis of juvenile rheumatoid arthritis anß characteristically, the adjacent vertebrae remai small in all diameters in this disease and the inte? vertebral disks atrophy and may calcify (Martetw Holt, and Cassidy, 1961). These changes are presumably due to growth disturbance and to atrophy secondary to non-use. This appearance. may be distinguished from that noted above io which the antero-posterior diameters of the vertebrai bodies are reduced. While ankylosing spondylitis may occasionally begin in childhood, it is probabl quite uncommon, particularly before puberty.

\section{Summary}

Extensive resorption of bone from the anteriof surface of the cervical spine is not uncommon if ankylosing spondylitis and is not to be confused with the growth disturbances seen in juvenils rheumatoid arthritis. Two examples of this deformity are illustrated. The radiological findings in one case clearly show that the onset occurred if adulthood, after the spine had reached full maturity Furthermore, one may expect a generalized reduo tion in the size of the cervical vertebral bodies 
juvenile rheumatoid arthritis, whereas in these adult cases the antero-posterior diameters are primarily affected.

\section{REFERENCES}

Martel, W., Holt, J. F., and Cassidy, J. T. (1961). "Radiologic Manifestations of Juvenile Rheumatoid Arthritis." Presented at the 62nd annual meeting of the American Roentgen Ray Society on September 27, 1961.

Romanus, R., and Ydén, S. (1955). "Pelvo-spondylitis Ossificans." Munksgaard, Copenhagen.

Weinmann, J. P., and Sicher, H. (1955). "Bone and Bones. Fundamentals of Bone Biology," 2nd ed., p. 134. Mosby, St. Louis.

Wilkinson, M., and Bywaters, E. G. L. (1958). Ann. rheum. Dis., 17, 209.

\section{Effets éloignés sur la colonne cervicale dans la spondylarthrite ankylosante}

\section{RÉSUMÉ}

Une résorption osseuse prononcée de la face antérieure de la colonne cervicale n'est pas rare dans la spondyl- arthrite ankylosante, et on ne doit pas la confondre avec des désordres de croissance observés dans l'arthrite rhumatismale juvénile. On décrit deux exemples de cette déformation. Les images radiologiques dans un cas montrent clairement que la lésion avait débuté à l'âge adulte, après que la colonne ait atteint sa maturité. Chez ces adultes, c'est le diamètre antéro-postérieur qui est surtout atteint, alors que, s'il s'était agi d'une ancienne arthrite rhumatismale juvénile, on aurait observé une diminution totale de volume des corps vertébraux.

\section{Efectos remotos sobre la columna cervical en la espondilartritis anquilosante}

\section{SUMARIO}

Marcada reabsorción de hueso en la superficie anterior de la columna cervical no es infrecuente en la espondilartritis anquilosante, y no se debe confundir con disturbios de crecimiento vistos en la artritis reumatoide juvenil. Se describen dos ejemplos de esta deformidad. Los hallazgos radiológicos en un caso muestran claramente que las alteraciones empezaron en la edad adulta, después que la columna había llegado a su pleno desarrollo. En lugar de la anticipada reducción generalizada en el tamaño de los cuerpos vertebrales en la artritis reumatoide juvenil, en estos casos adultos los diametros antero-posteriores se ven primeramente afectados. 
Prophylaxis of Occupational Rheumatic Lesions with Exercise Apparatus. (Zur Prophylaxe rheumatischer Arbeitsschäden am Bewegungsapparat.) SCHOGER, G. A. (1962). Z. Rheumaforsch., 21, 55.

Experimental Rheumatism induced with Vinidicol and Hydralazine. (Artritis experimentales por el Vincidol y la Hidralazina.) Pérez GiL, L. (1961). Rev. esp. Reum., 9, 156.22 refs.
Two Cases of Sjögren's Syndrome in Rome and their Therapy by means of Resochin. (Zwei Fälle von Sjögrensyndrom und deren therapeutische Beeinflussung durch Resochin.) Stoyanov, P. K. (1961). Med. Klin., 56, 957.7 refs.

Rehabilitation of the Rheumatic Patient. (A Reabilitação do reumático.) KLEIN, B., and Houli, J. (1961). Brasil-méd., 75, 314.

\section{CORRIGENDUM}

It is regretted that in the paper entitled "A Late Effect on the Cervical Spine in Ankylosing Spondylitis", by W. Martel, J. F. Holt, and W. D. Robinson, which appeared in the June, 1962, issue of the Annals, the three blocks for Fig. 1 were printed upside down. The correct version is shown below:

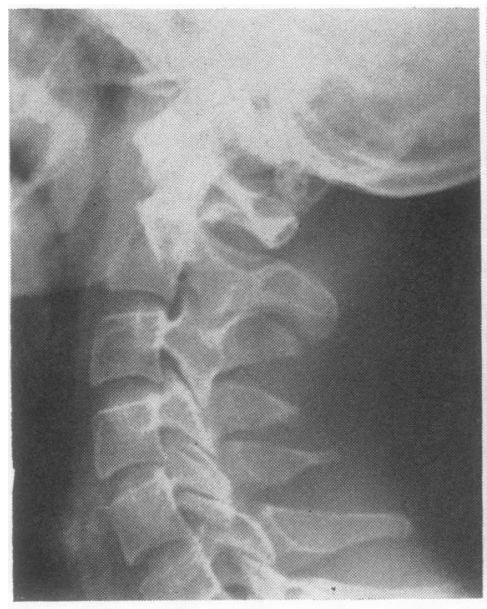

(a)

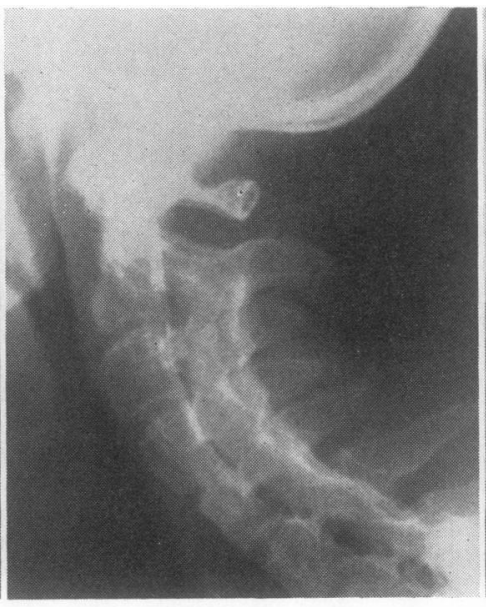

(b)

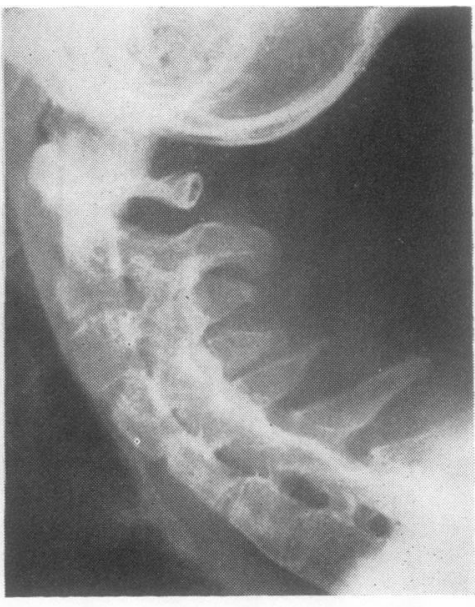

(c)

Fig. 1.-Case 1. (a) 1944 at age 27. Normal cervical spine. (b) 1949 . (c) 1954 . Extensive, progressive resorption of bone from the anterior surface of $\mathrm{C} 4,5$, and 6 . The vertical dimensions of these vertebral bodies are preserved. Note apophyseal ankylosis and atrophy of intervertebral disks. 